concerned possess the same essential properties during their brief sojourn in the living nexus as they do before and after.

In his address to the geological section, Professor John Joly, F.R.S., dealt with the effects of the presence of radium in the earth's crust and rocks on the distribution of the temperature gradients. By exhaustive determinations of the radium contents of various rocks and oceanic sediments, as well as by a systematic examination of the rocks of the Simplon and Central St. Gothard tunnels he found the change in temperature gradient observed to correspond exactly with the radium content of the rock. Space will not permit a proper abstract of this interesting address.

Leo Frank Guttman

\section{THE OFFICIAL INSPECTION OF COMMODITIES}

THE adulteration of articles of commerce is distinctly an evil of civilization. In the primitive state of man, nature supplied directly to the consumer the materials for food and raiment. There was no commerce and, therefore, none of the attending frauds. The savage vented his evil nature in murder, rapine and other of the grosser forms of crime, but he had no opportunity to practise the more intellectual frauds which civilization has made possible.

As soon as commerce came into existence, merchants began to cheat in weight and measure and to practise other commercial frauds, but at first they had comparatively few opportunities for adulteration, as the articles exchanged were for the most part crude products, such as grain and wool, which could not be successfully imitated. It was at a later period, when flour, cloth and other adulterable articles were bought and sold, that sophistication began to be a serious menace to the public welfare, and the evil, having once gained a foothold, increased as civilization advanced.

In recent times adulteration has increased enormously, particularly during the past half century.

There are several reasons for this alarming growth of fraud. In the first place, the number of commercial articles which can be successfully imitated greatly increased during the past century and is still increasing. We have to-day on the market an endless variety of foods, drugs, paints, oils, chemicals and fabrics which can be readily debased by the addition of foreign materials, without having the fraud evident to the purchaser.

The second reason is that the manufacture of butter, lard, cheese, starch, yarn, cloth and other articles, which formerly was carried on in the household, has been transferred to the mill and the factory. It can not be disputed that the cost of production has been reduced by this centraliza. tion of labor, and the housewife, incidentally, has been saved a deal of hard work, but the genuineness of the products has suffered as a consequence.

Still another cause for the increase of sophistication in recent years is to be found in the variety of materials adapted for use as adulterants which are now obtainable. Some of the materials which are commonly used for fraudulent purposes are products of the highest scientific research. I will mention as examples-oleo oil, cotton-seed oil, stearine and petroleum products, used for mixing with higher-priced fats and oils ; glucose syrup, the common adulterant $f_{c} \boldsymbol{r}^{\circ}$ molasses; artificial vanillin and coumarin, used in vanilla extracts; salicylic acid, benzoic acid and other food preservatives; coal-tar dyes, which serve as a mask for other food adulterants; wood alcohol, acetanilid and other coal-tar products, also morphine, cocaine and other habit-forming 
drugs, used in illegal medicinal preparations; artificial silk, often substituted for true silk, and so on. These products properly used are of great benefit to mankind, but altogether too often they have been parties to frauds and have thereby gained bad repute.

The extent to which adulteration is practised to-day is certainly cause for alarm, although too often the matter is overlooked or considered only from the humorous standpoint. The man who milks the cow with the iron tail, like the boy who steals watermelons, is looked upon as having perpetrated a good joke on the community, when in reality he is committing a criminal offense. All those who manufacture or knowingly sell adulterated products should be regarded as a menace to the welfare of the community, whether or not they are so declared by the laws of the land in which they live. If the article is merely fraudulent and causes no injury to health, the offender belongs in the same class with those who cheat in weight and measure and with common thieves; if, however, it is a menace to the safety or health of the community, he is several degrees lower in the moral scale.

The evil is not one which corrects itself, but, like other crimes, calls for vigilance on the part of both the individual and the state. The consumer should learn to distinguish, as far as possible, the pure from the false, and the state should enact and properly enforce laws for the further protection of the consumer. The necessity of legislative measures has been generally recognized and, as a consequence, inspection laws have been enacted in nearly every civilized country.

In the United States the inspection of milk, in a primitive way, was carried on in some of the large cities as early as the middle of the last century, and perhaps earlier; but it was not until a generation later that milk inspection was placed on a sound chemical basis, and not until still more recently that it has been carried out with the cooperation of the bacteriologist.

The first really extensive movement to prevent adulteration by official inspection and analytical control was the agitation among agriculturists which led to the establishment of experiment stations and the enactment of state fertilizer laws. On this occasion it is of special interest to recall that the first experiment station was established in Connecticut in 1875, largely through the efforts of Professor S. W. Johnson, of the Sheffield Scientific School of Yale University; and after two years' probationary existence at Wesleyan University, was permanently located in New Haven.

Following the example of Connecticut, other states, one by one, established experiment stations and enacted suitable fertilizer laws, until the movement had extended to all the states using commercial fertilizers in considerable quantities.

The official inspection work of the states for some years after the establishment of experiment stations was largely confined to plant foods, disregarding foods for man and the lower animals. It is hard to find an adequate explanation for this early solicitude for the rights of the vegetable kingdom, and the years of almost complete neglect of the dietary grievances of man and beast. Certain it is that the adulteration of foods for animate beings was quite as general as that of fertilizers, and the welfare of the community suffered to a much more alarming extent thereby; however, it is gratifying to note that this inconsistency in the laws has been remedied by more recent measures.

Massachusetts in 1883 and Ohio in 1886 enacted comprehensive food and drug laws, 
and, one by one, other states have fallen in line as "Pure Food States." Most of the food laws first enacted affected only dairy products, and their passage was secured chiefly through the efforts of dairymen to protect their interests; later, these laws were amended, or new laws were enacted, so as to include all articles of food and drink, and with the special view of protecting the consumer as well as the honest producer.

The enforcement of food laws, in most states, devolves on a Food Commission, but in a number of states it is in the hands of the Experiment Station or the Board of Health.

The passage of the National Food and Drugs Act in 1906 marked an important era in legislative measures for the protection of the public against fraudulent foods, beverages and medicinal preparations. This law not only renders more effective the state laws by checking the interstate shipment of fraudulent products, but also is proving a stimulus to the enactment of the laws in states previously without food inspection, and an important influence in bringing about uniformity in state laws.

In certain states the inspection of commodities has been carried a step farther. For example, the Maine Experiment Station inspects field and garden seeds with reference to their purity and vitality, and the stations in several other states exercise a semi-official control over the insecticides and fungicides on the market. In North Dakota a paint law is doing much to prevent such gross frauds as the substitution of fish oil and mineral oils for linseed oil, of whiting, barites and other cheap mineral powders for white lead and zinc white, etc. Ever since the discovery of petroleum, efforts have been made to protect the public from illuminating and fuel oils with low flash points and to-day more or less effective laws providing for the inspection of these products are in force in most of the states. Laws against substituting inferior alloys for standard alloys of gold and silver have also been enacted in some states, although, so far as I know, no official inspection of precious metals is in force.

From the foregoing brief statement of the growth of inspection in this country, it is apparent that the sentiment in its favor is wide-spread and the classes of commodities concerned are on the increase. Under the conditions of trade that now prevail inspection is almost a necessity and there appears to be good reason for making the official control of the commodities already named universal throughout the country and extending the system so as to cover still other commodities.

If petroleum is inspected, why not coal; if paints and oils, why not lime and cement; if foods, why not raiment?

The fact that all coal sold for the same grade is not of equal value is well known to those chemists who have studied coal analyses, and also to consumers who have observed the occurrence of slate in the coal itself and clinkers in the ashes. The government inspects and analyzes the coal it buys and it seems not unreasonable that the consumer should also be protected. Such an inspection of coal, if feasible, would be a matter of public economy, not, as in the case of illuminating oils, of public safety.

Building frauds concern both the safety and the pecuniary welfare of the community. It frequently happens that the cupidity or ignorance of the builder leads him to use poor lime and cement, or mix an undue amount of sand with his mortar, thus weakening his structures and imperiling life. The rigid inspection of buildings in the cities does much to protect the public from these dangers, but this inspection is 
local and seldom as comprehensive as could be desired. The analytical control of certain building materials may not be impracticable.

The last class of commodities which we will consider is one which, next to foods and drugs, is perhaps most in need of inspection. I refer to textiles and other materials for wearing apparel.

The frauds in woolens have been notorious. Sixty years ago when my father started in business as a country merchant, he learned the value of the match test for cotton, and throughout his life whenever purchasing woolens for personal use he never failed to draw out threads and apply this test, often to the chagrin of the seller. Twenty years ago in this very city I purchased a suit of clothes of splendid appearance at a price which was almost, if not quite, beyond my means. In a few weeks the so-called "all wool" material of the suit showed the characteristic faded appearance of cotton, and was hardly fit for the garb of even a struggling chemist. During the past year one of my friends made a similar purchase in the heart of the shopping district of Chicago. At his request I examined the goods and reported that the warp was all cotton and the woof a mixture of cotton and shoddy. Needless to say there was no redress for this gross imposition.

Frauds in other textiles are not uncommon. So-called linen often contains cotton, hemp and tow; "all silk" often has a cotton back, and much that appears like silk is so-called artificial silk or even mercerized cotton.

There are also glaring frauds in shoes, gloves and other leather goods, felts and furs. Split leather is sold for calf skin, lamb and other inferior leather for kid, wool felt for fur felt, imitation furs for the genuine, and so on.
The more the subject is investigated, the more wide-spread and ingenious appear to be the frauds practised.

Opponents of paternalism will doubtless find cause for alarm in the mere suggestion of the further extension of inspection. They will feel that the rights of the merchant class are threatened and that the dangers from indiscreet and corrupt officials are greater than those from adulteration.

It can not be denied that there are diffculties in the way, and great care should be exercised in framing new laws, but if the present inspection of commodities is, on the whole, an advantage to the public, it seems but logical to extend the system so as to cover other necessities of life liable to adulteration. The inspection should be primarily in the interest of the consumer.

The manufacturer and dealer can usually take care of themselves, as their knowledge of the trade enables them to buy wisely, and in case of doubt submit samples to the chemist for analysis. For years sugar refiners, packing houses, iron and steel works, fertilizer manufacturers, cement works and other manufacturing industries have maintained laboratories for the examination of their raw material, and have proved themselves quite able to look after their own interests.

With the consumer the case is different. $\mathrm{He}$ is usually ignorant of trade practises and of the steps necessary to secure chemical evidence of adulteration and redress in the courts. Even if he can afford to seek the advice of the chemist and the lawyer, he is at a disadvantage in fighting large houses with their array of professional advisers. He needs the protection of a system of legal inspection which follows up and punishes a fraud in a five-cent purchase with as much care as a thousanddollar swindle.

Incidentally, the honest producer is the 
gainer by inspection, as the prevention of dishonest competition is distinctly to his advantage. In the past reputable business houses have been among the first to favor adulteration laws, and it is not improbable that they would welcome further measures. It should be remembered, however, that the trade is ever jealous of its rights and is quick to resent any unnecessary interference.

The chemist has been an important factor in inspection, as on him has devolved the important task of securing evidence as to the character or purity of products and presenting this evidence either in official reports or by testimony in court.

The Association of Official Agricultural Chemists, since its inception, has been preeminently a body of inspection chemists and doubtless would never have existed had it not been for laws affecting the sale of fertilizers and foods. The same may be said of the Section of Agricultural and Food Chemistry of this Association. Of the 28 papers to be read at this meeting before the section, at least 19 relate directly or indirectly to inspection, and a great majority of the listeners will doubtless be inspection chemists.

The extension of inspection is continually opening up new and fascinating realms of investigation, and it will be a long time before the analyst need cry for new worlds to conquer.

\section{Chicago Laboratory of Bureau of Chemistry, \\ U. S. Department of Agriculture}

\section{THE AMERICAN SOCIOLOGICAL SOCIETY}

THE third annual meeting of the American Sociological Society will be held at Atlantic City, N. J., from December 28 to 31, inclusive, in conjunction with the annual meetings of the American Economic Association, the American Statistical Association and the American Association for Labor Legislation.
The Sociological Society will hold seven sessions, one of which will be a joint meeting with the Economic Association and another of which will be a joint meeting with the American Statistical Association. All seven sessions, however, will be devoted to a discussion of some aspect of the general topic "The Family in Modern Society." Thi, general topic has been divided as follows:

1. Relation of the family to social change. (President's address.)

2. How do home conditions react upon the family?

3. Are modern industry and city life unfavorable to the family?

4. How does the woman movement react upon the family?

5. Has the freer granting of divorce proved an evil?

6. How far should the state go in individualizing the members of the family?

7. How far should family property be conserved and encouraged?

Detailed programs can be had by applying to the Secretary, Professor C. W. A. Veditz, George Washington University, Washington, D. C.

\section{THE “UNIVERSITY TABLE" AT THE NAPLES ZOOLOGICAL STATION}

For a number of years in the past a table was maintained at the Naples laboratory under the above title, half the cost being met by the late William E. Dodge in the name of Columbia University, and half by contributions from other sources. Owing to lack of regular support the subscription for this table unfortunately lapsed for several years. Friends of the university have now made it possible to renew the subscription, and it is hoped that the table may now be permanently maintained under the name of the "Columbia Table." Its use is open to all qualified Americans and applications may be sent to Professor E. B. Wilson, Columbia University, New York City.

\section{SCIENTIFIC NOTES AND NEWS}

The Nichols Medal of the American Chemical Society has been awarded to Professor William A. Noyes, of the University of 